DOI: https://doi.org/10.24127/ajpm.v9i1.2655

\title{
DEVELOPMENT LEARNING MEDIA OF MATH-CHA TO SUPPORT VOCATIONAL HIGH SCHOOL REVITALIZATION
}

\author{
Rachmawati $^{1}$, Rina Wijayanti ${ }^{2}$, Era Dewi Kartika ${ }^{3 *}$ \\ ${ }^{1,2,3}$ Pendidikan Matematika, IKIP Budi Utomo Malang, Indonesia \\ * Corresponding author. Jln Citandui 46 Purwantoro Kota Malang \\ E-mail: $\quad$ rachmawati603@gmail.com ${ }^{1)}$ \\ $\underline{\text { rina.statistika12@gmail.com }}^{2)}$ \\ elforgera@gmail.com ${ }^{3 *}$
}

Received 23 January 2020; Received in revised form 24 February 2020; Accepted 28 March 2020

\begin{abstract}
The purpose of this study is to produce character building learning media based on m-learning mathematics with a contextual approach that is expected to provide convenience for students and teachers in supporting the revitalization of vocational education. This research is a development research. This research method refers to the 4D development model (Define, Design, Develop, and Disseminate). Development of Math-Cha applications with the help of Android Studio IDE software, and Fire Base. The result of the development in the form of a learning media product is the Math-Cha application which is installed on an Android device. The Math-Cha application consists of material and evaluation. The $\mathrm{m}$ learning media on mathematics is given reinforcement by integrating character education and contextual presentation so that it supports the revitalization of vocational education. Content in the application begins by introducing character values into mathematical problems at the apperception, material and evaluation stages. Evaluation of validity aspects is based on the validation of media experts and material experts who are valid criteria with an average of 3.61. The evaluation of practicality aspects based on student response questionnaire was in the good criteria of 3.72 and the teacher's questionnaire in the criteria of good was 3.40. The assessment of effectiveness aspects based on student test results is in good criteria with an average of 86.6. Math-Cha supports learning, use easily, and it can be used anywhere and anytime.
\end{abstract}

Keywords: Character building; contextual approach; m-learning; revitalization of vocational education.

\begin{abstract}
Abstrak
Tujuan penelitian ini untuk menghasilkan produk media pembelajaran matematika m-learning berbasis pendidikan karakter dengan pendekatan kontekstual yang diharapkan memberikan kemudahan siswa dan guru dalam menunjang revitalisasi pendidikan SMK. Penelitian ini merupakan penelitian pengembangan. Metode penelitian ini mengacu pada model pengembangan 4D (Define, Design, Develop, dan Disseminate). Pengembangan aplikasi Math-Cha dengan bantuan software Android Studio IDE, dan Fire Base. Hasil dari pengembangan berupa produk media pembelajaran yaitu aplikasi Math-Cha yang terinstall di perangkat Android. Aplikasi Math-Cha terdiri dari materi dan evaluasi. Media pembelajaran m-learning pada matematika diberikan penguatan dengan mengintegrasikan pendidikan karakter dan disajikan secara kontekstual sehingga mendukung revitalisasi pendidikan vokasi. Konten dalam aplikasi dimulai dengan mengenalkan nilai-nilai karakter kedalam permasalahan matematika pada tahap apersepsi, materi dan evaluasi. Penilaian aspek kevalidan berdasarkan penilaian validator ahli media dan ahli materi yang berada pada kriteria valid dengan rata-rata 3,61. Penilaian aspek kepraktisan berdasarkan angket respon siswa berada pada kriteria baik sebesar 3,72 dan angket respon guru yang berada dalam kriteria baik sebesar 3,40. Penilaian aspek keefektifan berdasarkan hasil tes siswa berada pada kriteria baik dengan rata-rata 86,6. Math-Cha mendukung dalam pembelajaran, tingkat penggunaannya relatif mudah, pembelajaran dapat digunakan dimana saja dan kapanpun.
\end{abstract}

Kata kunci: M-learning; pendidikan karakter; pendekatan kontekstual; revitalisasi pendidikan SMK. 
DOI: https://doi.org/10.24127/ajpm.v9i1.2655

\section{INTRODUCTION}

The development of mobile device technology is more implemented in the field of education such as elearning, online-learning, web-based training, online courses, etc. According to Tasri (2011) many educational institutions utilize e-learning systems to improve the ease and flexibility of learning. Some of these conveniences are the driving factors for developing a mobile application system to be innovated in learning into mobile learning. Innovation of mobile devices in the era of industrial revolution 4.0 in the field of education changes the way students learn that is used as a learning media in order to create a more interesting and communicative learning situation.

M-learning is a mobile based learning model (smartphone electronic device). Mobile devices are here as a media to present learning information, access material learning, provide direction wherever and whenever. Compared to conventional learning, $\mathrm{m}$ learning provides many opportunities and increases informal interactions between teachers and students (Darmawan, 2012). Thus, initially the learning process meeting only takes place in the classroom, but with the existence of m-learning can continue after class meetings and at any time.

Several studies relating to the development of multimedia-based learning media, show positive results on the learning process (Istiqlal \& Wutsqa, 2013; Setyadi \& Qohar, 2017; Aini, Anggoro, \& Putra, 2018). None of these studies have examined about development learning media of mathcha to support vocational high school revitalization.

Technological advances in education can have a positive and negative impact. The existence of smartphones in the millennial era can have a positive impact, namely the easy of learning and the availability of learning resources in the field of education. If examined comprehensively the positive impact greater than the negative impact then supported by knowledge and awareness based on faith and piety and continuous supervision of parents. Thus technological advances for children's education need to be balanced with Character Building.

This character building must be implemented by every school. Character building in schools aims to improve the quality of organization and the results of school education which leads to the achievement of character formation of students. The character formation of students is one of the goals of national education. UU Sisdiknas of 2003 said that education does not only form intelligent Indonesians, but also has a personality or character, so that later generations of nations will develop and develop characters that breathe the noble values of the nation and religion. Kemendikbud encouraged a paradigm teachers to be able to carry out their role as professional educators not only to educate students, but also to shape their positive character to become a gold generation of Indonesia with the $21 \mathrm{st}$ century's skill.

The role of education in students not only hard skills, but soft skills. Lickona (2012: 148) said that academic learning and character building must be in line together. The formation of students' soft skills is by character building. According to Aziz (2012: 197) the simplest character building strategy can be implemented, (1) through figures, human figures (figures) who can provide inspiration to other humans 
(2) through example, in the form of words or behavior (3) through continuous education, not only education in schools but the home environment is also actively involved in providing value transformation (4) through intracurricular activities, each subject area must always contain character building (5) through extracurricular activities, each extracurricular activity by inserting values character.

Teacher as a model and control when implementates character building in class. The teacher as a model is the teacher must be able to be an example of the behavior of character values developed. The teacher as a control is the teacher controlling the behavior of students to suit character values. The teacher can integrate character values into each subject area. Thus it will become a habit for students to apply character values. Basically learning activities in addition to making students master the targeted competencies, are also intended to make students recognize, have awareness / care and shape behavior according to the values of national character.

Mahardani (2018) and Subekti (2016) stated that character education is an important element in improving the quality of human resources. One of the efforts taken by the government to improve the quality of human resources is the revitalization of vocational education. Application based on character education is expected to be able to support the revitalization of vocational education, combine with a contextual approach able to facilitate students in understanding the material of mathematics. Elaine (2011) said that a contextual approach emphasizes the thought process to involve students to find the relationship of material that is understood with real-life reality. Contextual approach can also improve learning achievement (Sakti \& Sujadi, 2014) and enhance the ability to understand mathematical concepts (Yadin, Rohaeti, \& Zanthy, 2019).

Competitiveness and skill are the demands of the industrial world of work. Vocational School as one of vocational education gives birth to a workforce making a strategy to produce output of graduates who are highly competitive and skilled. This strategy is known as the revitalization of vocational education. Vocational character building as a manifestation of the mental revolution movement is the revitalization of the productive curriculum by graduating 7.2 million polite, independent and creative technicians up to 2019.

The purpose of this study is to produce character building learning media based on m-learning mathematics in class. This media are expected to facilitate students and teachers in supporting the revitalization of vocational education.

\section{METHOD}

The type of research is research and development (R\&D). The development model refers to to $4 \mathrm{D}$ model. The location of the research is SMKN 2 Malang. The research subjects were class $\mathrm{X}, 24$ students of Catering Service of SMKN 2 Malang.

The development research phase consists of define, design, develop and disseminate. Beginning with the Define stage, namely the activities carried out, namely observation and interviews regarding the analysis of the initial objectives, analysis of students, analysis of concepts to teachers and students. The concepts and assignments in mathematics subjects in class $\mathrm{X}$ even 
semester are Trigonometry and Matrix. The next stage is Design includes preparing instruments in the form of material, evaluation, and application design. The next stage is Develope. At this stage validate mobile learning media in the form of a math-cha application by expert validators to produce a valid, practical and effective application. Effective applications are applications that easy to use, because in application development, aspects of ease of use must be considered (Dewi, N.R., 2016). The development procedure ends with the disseminate stage. The deployment of math-cha applications via the web and can be downloaded via the link bit.ly/mathchaujicoba.

Instruments and data collection techniques include expert validation sheets, test questions and student and teacher response questionnaires.

a. Expert validation sheet. Validation was carried out on media expert validators, material expert validators. The expert validation sheet contains an expert assessment of the validity of the product being developed

b. Test questions. The use of tests is for learning outcome evaluation instruments. The use of tests to determine the effectiveness of the instrument against the Math-Cha application concept

c. Questionnaire of user. User questionnaire to find out the effectiveness of the Math-Cha application. The questionnaire is intended for users, namely teachers and students. Furthermore, the results of the user questionnaire were used as material for revision of the product developed.

Data Analysis Techniques includes analysis of expert validation results, analysis of test result, analysis of the results of the user questionnaire.

a. Analysis of expert validation results

Assessment of the results of expert validation is used to determine the validity of the product being developed. Assessment uses 4 scales, namely 1 (not good), 2 (good enough), 3 (good), and 4 (very good). The product is said to be valid if the average score of expert validation results is valid. Calculation of the average score of assessment from experts as follows.

$$
X=\frac{\sum x}{n}
$$

$X$ is a average expert assesment, $\sum x$ is the number of expert assessment scores, dan $n$ number of assessment indicators in the validation sheet. Assessment criteria from experts are presented in Table 1.

Table 1. Expert validator assesment criteria.

\begin{tabular}{cc}
\hline $\begin{array}{c}\text { Average Rating } \\
\text { Score }\end{array}$ & $\begin{array}{c}\text { Criteria } \\
\text { assesment }\end{array}$ \\
\hline $3 \leq X \leq 4$ & Valid \\
$2 \leq X<3$ & quite valid \\
$1 \leq X<2$ & not valid \\
$0 \leq X<1$ & invalid \\
\hline
\end{tabular}

b. Analysis of test results

The test results are used to the effectiveness of the product. The product is said to be effective if the average test results are included in the sufficient criteria, namely the KKM value set by the school reaches 65.

c. Analysis of the results of the user questionnaire

The results of the user questionnaire are used to the practicality of the product. The product is said to be practical if the average questionnaire score is in good criteria. Assessment 
DOI: https://doi.org/10.24127/ajpm.v9i1.2655

uses 4 scales, namely 1 (disagree), 2 (quite agree), 3 (agree), and 4 (strongly agree). The calculation of the user questionnaire is as follows.

$$
X=\frac{\sum x}{n}
$$

$X$ is the average student questionnaire score, $\sum x$ is the number of student response assesment scores and $n$ the number of assesment indocator in the student response questionnaire. Assesment criteria are presented in Table 2.

Table 2. Assesment criteria student questionnaire.

\begin{tabular}{cc}
\hline $\begin{array}{c}\text { Average Rating } \\
\text { Score }\end{array}$ & $\begin{array}{c}\text { Assesment } \\
\text { Criteria }\end{array}$ \\
\hline $3 \leq X \leq 4$ & Very Good \\
$2 \leq X<3$ & Good \\
$1 \leq X<2$ & Good Enough \\
$0 \leq X<1$ & Not Good \\
\hline
\end{tabular}

\section{RESULTS AND DISCUSSION}

Development refers to the 4D development model, namely define, design, develop, and disseminate. The product is a mobile application called Math-Cha on the Android operating system. The name Math-Cha stands for Mathematics Based On Character Building

\section{Define}

The initial stage in developing the Math-Cha application. Previous researchers conducted observations and interviews with teachers and students in mathematics learning activities. Through observation and interviews, the fact is that there are no innovative teaching materials that contain character building used in the process of teaching and learning activities. Student want further material ourside off class meeting hours, with the Math-Cha application this is fulfilled because students can repeat evaluations and practice questions outside of study hours even at home. The concepts and assignments in this mathematics subject are learning material in class $\mathrm{X}$, choosing a contextual approach as a learning approach to be used. Supporting software needed in building applications is the Android Studio IDE, and Fire Base as database support. The database aims to store student identity and values.

\section{Design}

The design phase is the design stage of the product being developed. The design step is to arrange learning material that contains character values and test evaluations to measure students' understanding.

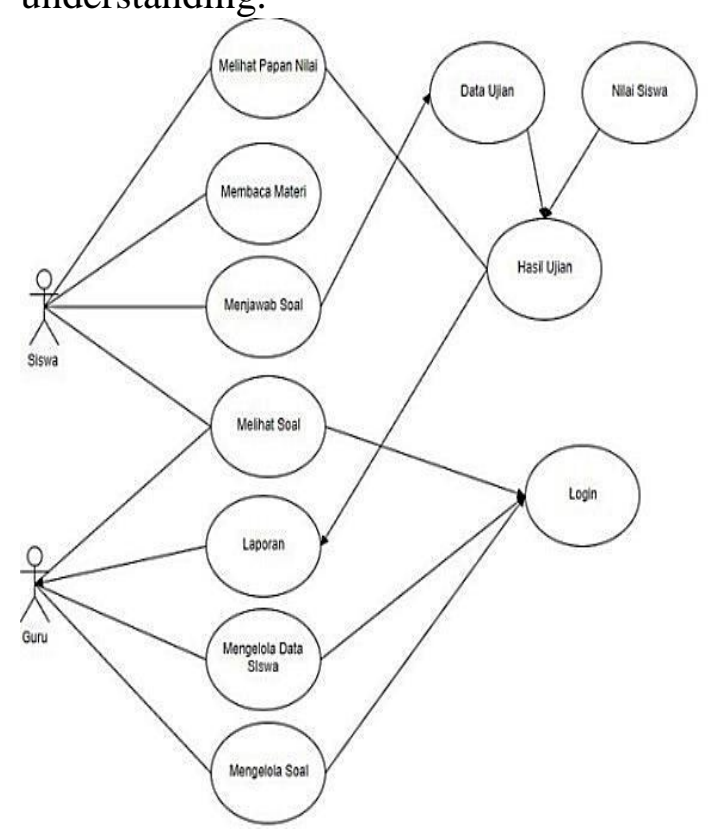

Figure 1. Use Case diagram of the Math-Cha application system.

Users of this application are students and teachers. Users as students to understand the material and work on evaluations, while users as teachers manage the material and questions 
DOI: https://doi.org/10.24127/ajpm.v9i1.2655

about evaluation. The right of access to the material can be used offline mode, while the evaluation must use online mode, meaning students must be connected to the internet. Before working on the questions, students are required to Login through a Google account or Facebook. Login aims to manage student data and learning outcomes. Students who are already logged in, the value of the learning outcomes will be listed in the "Papan Nilai" The Use Case diagram in the Math-Cha application system is shown in Figure 1

The main part of the design of the Math-cha application consists of Menu, Leaderboard and Account Profile. The appearance of the main parts is in Figure 2.

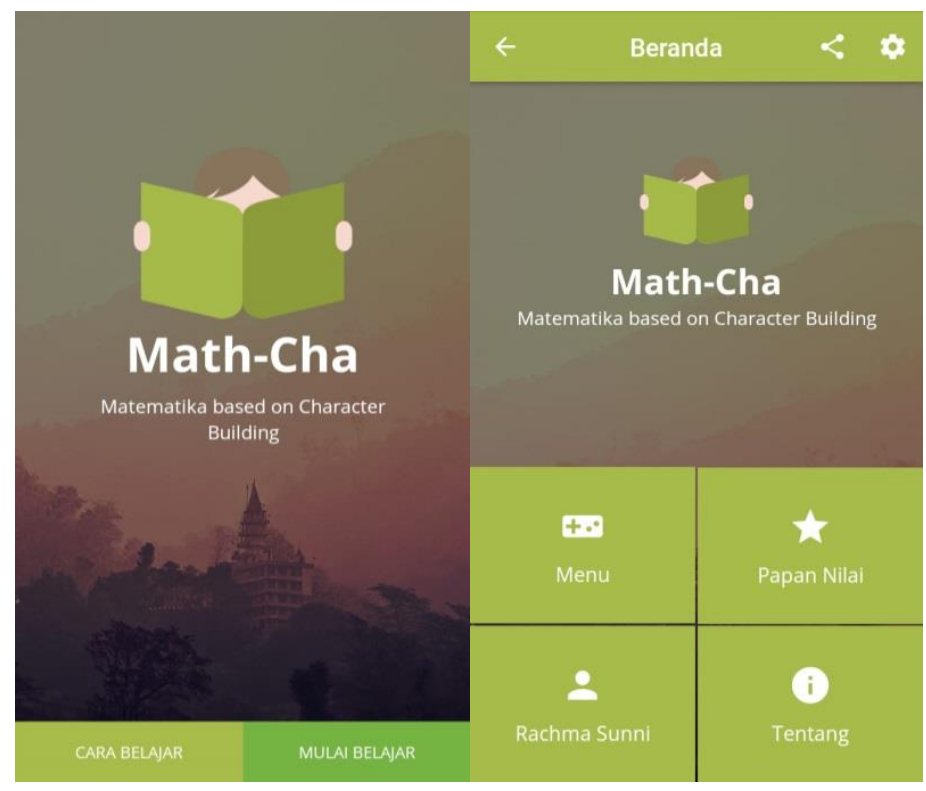

Figure 2. Main menu

Мепи

The menu section consists of material and categories. The implementation of the material is integrated with character values using a contextual approach. The appearance of the material section is in Figure 3.

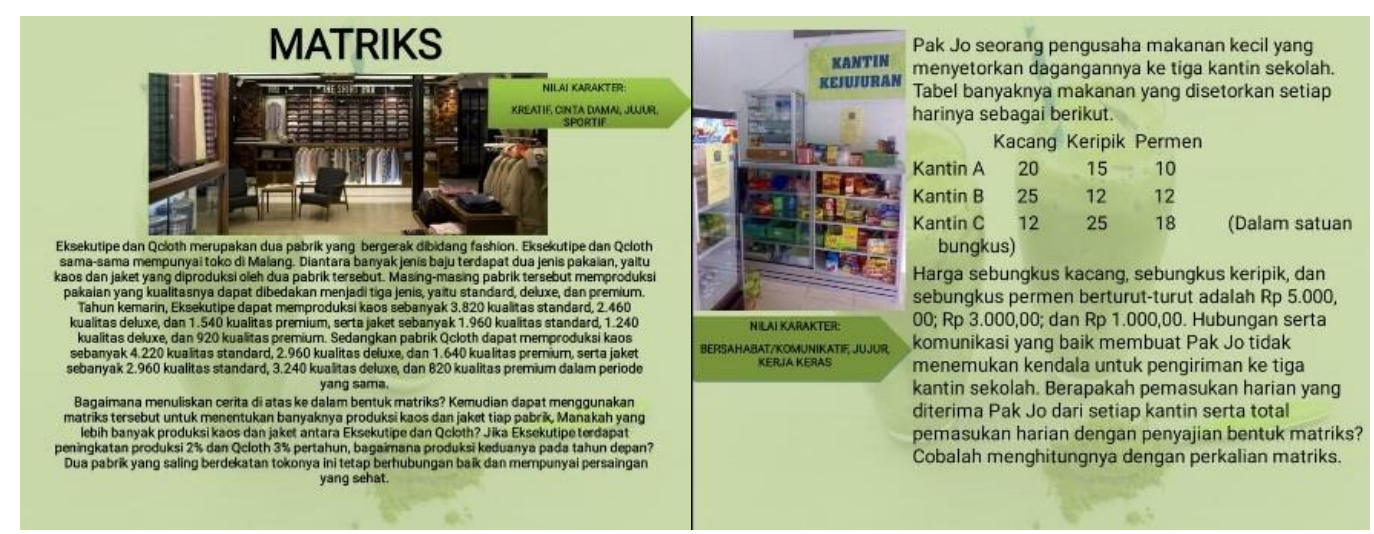

Figure 3. Material section. 
DOI: https://doi.org/10.24127/ajpm.v9i1.2655

While the category contains an evaluation that aims to measure students' understanding. If the value is less than the KKM standard, students are welcome to repeat (remiadial) by clicking the "MUAT ULANG". The appearance of the category section is in Figure 4.

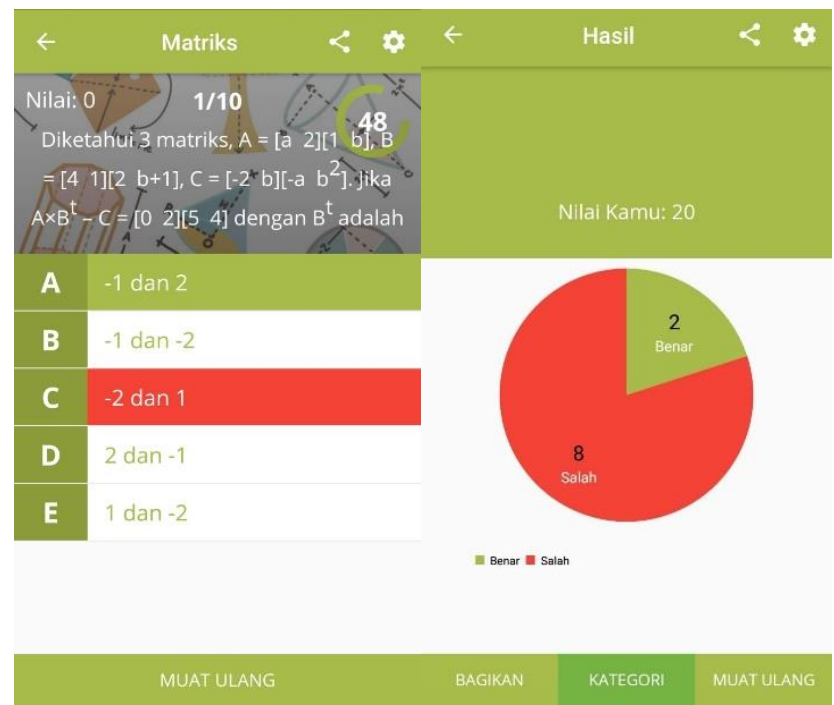

Figure 4. Chategory.

\section{Panel Siswa}

The Panel Siswa section contains student data. There are two choices of student accounts, namely through a Google account or Facebook account. There is no difference if using one of these account alternatives. Students are given material access rights in offline mode, while categories (evaluations) students must access in online mode. Online mode means that students are required to connect to an internet connection. The purpose of this online mode is to keep student names and values in the Math-Cha application system database. Thus, before working on an evaluation in the "Kategori" section students are required to $\log$ in to the account first. After that user would enter the each Facebook or email account.

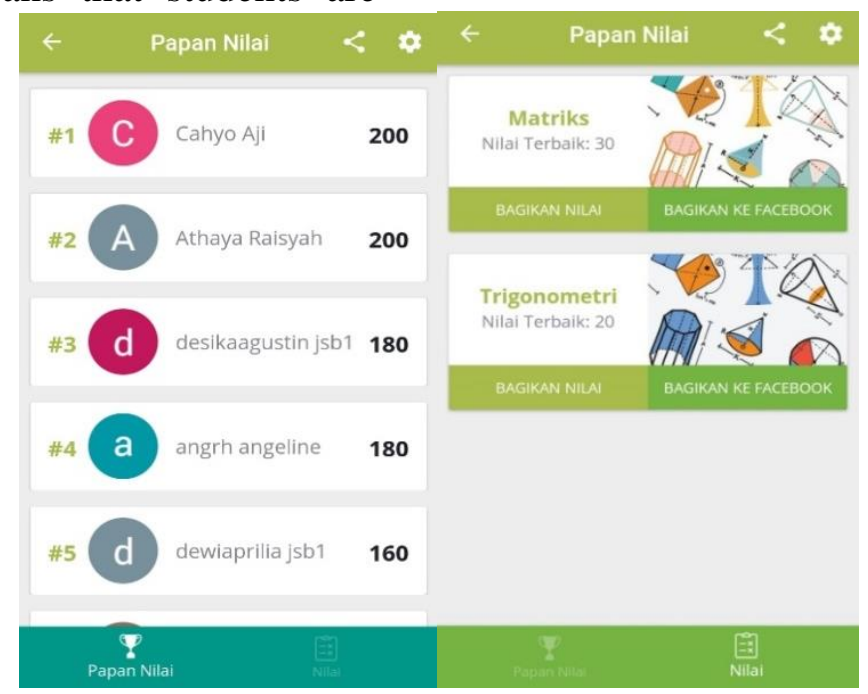

Figure 6. Papan nilai display. 
DOI: https://doi.org/10.24127/ajpm.v9i1.2655

\section{Papan Nilai}

The Papan Nilai section has values based on chapter and accumulative learning outcomes. Student data and leaarning outcomes are stored in the application system database. Figure 6 shows the display of the leaderboard in the Math-cha application.

\section{Develope}

Develope is the result of validity, practicality, effectiveness, and product improvement. At this stage testing validity, practicality, and effectiveness is carried out. Validity testing by validating the product step is developed to the media expert validator who is a mobile learning lecturer and material expert validator who is a lecturer in Matematika SMA. Evaluation of media expert validators in terms of aspects of functionality, usability, and integrity. Evaluation of media expert validators in "Valid" criteria. Based on the results of media expert validation, there are suggestions that on the display in the Kategori Menu, the writing of the Matrix is better captured so that the Matrix symbol does not make students confused. Furthermore, the assessment of the material validator is reviewed from the aspects of content, presentation, and language. From the results of expert validation, the average score of the assessment that is in valid criteria is obtained. The results of expert validation are shown in Table 3.

Table 3. Expert validator assesment.

\begin{tabular}{lcc}
\hline Validator & $\begin{array}{c}\text { Average } \\
\text { scoring } \\
\text { assesment }\end{array}$ & Criteria \\
\hline Media & 3.73 & Valid \\
$\begin{array}{l}\text { Expert } \\
\text { Material }\end{array}$ & 3.50 & Valid \\
Expert & & \\
\hline
\end{tabular}

Testing the practicality of the media through testing to users by providing a questionnaire. Users include teachers and students. The teacher as a user to enter practice and material questions while students as users to understand the material and work on the problem. The trials for students were carried out as much as $2 \mathrm{x}$ namely small group trials and large group trials. The average results of the questionnaire responses of small group students reached a value of 3.30 (good criteria). The purpose of small group trials is as an evaluation of the development of an unfinished design Then tested in a large group with a score of 3.72 (good criteria). The results of the questionnaire responses from teachers obtained a value of 3.40 (good criteria). Based on the results of the teacher and student questionnaires, the Math-Cha application was declared practical. Testing the effectiveness of the media is given through giving test questions. The average score of students' test scores reached 86.6 (criteria good $>65$ ). Based on the score of the test results, the media of the Math-Cha application is declared effective.

Evaluation of validity aspects based on the assessment of media expert validators and material experts who are in valid criteria with an average of 3.61. The assessment of practicality aspects based on student questionnaires was in good criteria of 3.72 and questionnaire responses of teachers who were in good criteria were 3.40. Assessment of the effectiveness aspects based on student test results is in good criteria with an average of 86.6. The average score produced is greater than the KKM standard set by the school. 
DOI: https://doi.org/10.24127/ajpm.v9i1.2655

\section{Disseminate}

The Math-Cha application is disseminated via .apk file transfer on an Android device or downloaded in link https://bit.ly/mathchaujicoba. The MathCha application is used in all class $\mathrm{X}$ math subjects in SMKN 2 Malang so that it can be used as a support for mathematics learning media.

\section{Study of the final produk}

The development of mobile learning media in this study has been carried out through the stages in the 4D development model, namely define, design, development, and disseminate. Through these four stages researchers can find out the quality of learning media products that are developed that the media are feasible and meet the criteria of validity, practicality, and effectiveness. Learning media was successfully developed using Android Studio IDE and FireBase as database support. The resulting learning media products are in the form of an android package (.apk) format. The APK file format is an application installation file on an Android device. If the apk file is opened on an Android device, the automatic media application is installed on the device.

The learning media products of the Math-Cha application have the following characteristics: (a) The product is a mobile-learning media that supports mathematics learning in grade $X$ vocational school that contains character building. (b) Products in the form of software (apk) that can be operated using an Android device. (c) media can be used during learning at school and outside the KBM. (d) products provide material explanations (in offline mode) and kategori (in online models). (e) the product requires student to Login into so that data and skoring assesment are stored in the system database.

The validation results show that media experts stated that the media in the criteria are valid with a total value of 67 and an average value of 3.7. The assessment was reviewed from the aspect of functionality with the acquisition of $34 \%$, the aspect of reliability with the acquisition of $25 \%$, the aspect of usability with the acquisition of $34 \%$ and the aspect of integrity with the acquisition of $11 \%$. In the aspect of regularity and consistency of appearance of each page still needs to be improved. The matrix symbol display cannot be displayed perfectly on the Android screen. This is due to the availability of inadequate matrix symbol facilities so it is recommended to capture matrix symbols from other media displays. In the aspect of reliability, the strength and durability of the program needs to be improved because the process of distributing applications still uses the help of file transfer software such as share it, making it vulnerable to contracting malware. In the aspect of reusability of the layout of the text on the material there is a shift that needs further improvement. The use of Math-Cha application media is very easy, interesting, and useful. Ease of operating the Math-Cha application due to the simple interface and use of language. The attractive aspect of the Math-Cha application from an attractive appearance with soothing green shades. Subconsciously students feel in a beautiful tea garden atmosphere, calm, and soothing, while the taste of MathCha itself is a favorite of teenagers. This is reinforced by Moelbatak (2016) that attractive multimedia learning media can increase student enthusiasm and interest in learning. 
DOI: https://doi.org/10.24127/ajpm.v9i1.2655

The results of the material validator showed that the material expert gave a total value of 42 and an average of 3.5 validation results meant that they were in the valid criteria. Indicators of material validator assessment include content aspects with the acquisition of $21 \%$, aspects of presentation with the acquisition of $24 \%$, and linguistic aspects with the acquisition of $55 \%$. In the aspect of content with indicators of material coverage, material accuracy, and the association with character values are considered good. In the aspect of the presentation with indicators of presentation techniques, supporting the presentation of material, and the presentation of learning according to the learning method is considered good. Linguistic aspects with indicators in accordance with the development of students, communicative, straightforward, coherence, and consistency of the use of terms and symbols / symbols are considered good. The suggestion from the material expert validator is internalization of character values into contextual learning adapted to work culture in the industrial world so as to encourage an increase in vocational student soft skills.

At SMK there are 3 groups of subjects namely normative, adaptive, and productive. Normative subject groups for example Religious Education, Civics Education, Indonesian Language, and Cultural Arts. While the adaptive study group for example Mathematics, English, Natural Sciences, Social Sciences, KKPI, and Entrepreneurship. Mathematics at SMK is an adaptive subject. The duration of teaching and learning activities is only $2 \times 45$ minutes. Based on interviews with students in the field of face-to-face time during teaching and learning activities is very less to understand mathematics. According to students mathematics in the category of lessons that are difficult to understand. Mathematics teaching and learning activities in Class $\mathrm{X}$ Catering only use modules as teaching material and use the internet occasionally for browsing. Students need additional study and practice time monitored by the teacher. With the Math-Cha learning media application that can be accessed anywhere and anytime outside school hours, this media can guide and increase understanding of mathematical concepts. The teacher can control students because the student identity is stored in the system database. The use of android-based media is one of the applications of the 21st century learning style (Calimag et al, 2014). Calimag also mentions the implementation of learning using smartphones and tablets can have a positive impact on the cognitive, metacognitive, affective, and socio-cultural. This is supported by Elyas (2018) argues that the learning process with e-learning provides flexibility in determining the time and place. Students can study anywhere that has internet access. Even with the development of technology, every public place has a free wifi service so that financially learning styles with elearning can reduce costs.

During a large group trial, interviews were conducted with two students, the results of which said students were very happy to learn with the learning media Math-Cha application. Other students also added that they would be happier if all mathematics material was presented as in Math-Cha, learning would be fun and easy to understand. In addition, researchers made observations in the use of this application. There are some 
students who have difficulty using this application due to limited mobile memory or poor $\mathrm{WiFi}$ signal and internet signal. However, students help to help friends who have difficulty using wifi signal limitations and tethering between smartphone devices, this shows good character education. Students consisting of 9 round tables with 3 to 4 people at each table discussing for the use and resolution of evaluation questions contained in MathCha. $90 \%$ of students in the class succeed in using the Math-Cha application, because the signal is constrained by $70 \%$ of students who can complete the evaluation questions to completion. From the evaluation results obtained in the Math-Cha application it appears that there are two people with perfect scores followed by other values not far from perfect scores.

The items in the Math-Cha evaluation have gone through the process of content validity by experts. The assessment aspects were examined in terms of the accuracy of the contents of the test sheets and aspects of language and writing questions. The Aspect of Accuracy of the contents of the test sheet includes (a) the items in accordance with the Core Competencies and Basic Competencies. (b) Item questions are formulated briefly and clearly. (c) The suitability of the test questions to the level of ability (d) Questions in accordance with the indicators so that they can measure the ability to apply concepts in various forms of mathematical representation, the ability to classify objects based on whether or not the requirements that form the concept, the ability to link various mathematical concepts with life contextual. While the aspects of language and writing questions include (a) The language used is a language that is good and correct according to the rules of the Indonesian language. (b) Sentences of communicative questions and in accordance with students' level of thinking. (c) The formulation of the subject matter does not contain expressions that mean uncertainty (ambiguous). (d) The accuracy of the dialogue / text with the story / material. The results of the assessment of content validity by experts indicate the acquisition of an average score of 3.25 validation results with valid criteria so that the items can be used as evaluations.

Student pre-test results on trigonometry material show that students are not disciplined in writing the naming of elements in trigonometry, students also do not show the spirit of completing each question given. Items in trigonometry material presented with many formulas require students to have an unyielding attitude, while in the results of this initial test there are quite a number of formulas that are not memorized correctly by students. Pretest results for the matrix material, students show a lack of discipline in writing matrix notation, there are students who write a matrix with only two straight lines and there are students who write it with parentheses. Students also show a lack of hard work in solving problems because they find it difficult or forget the formula. Therefore we introduce Matcha to students. Math-cha presents material with a contextual approach that is suitable for students' daily lives and is based on character education that will make student learning process more enjoyable and effective.

The test results show that with the use of Math-cha, students are more disciplined in their work, and there is good cooperation between students. 
Hard work and sportsmanship shown by students in the evaluation contained in Math-cha. Initially students who only scored 70 , returned to read the material, then tried again to work on the problems and get higher grades. Evaluation with Math-Cha was followed by 24 students, where there were 3 students scored 75, 11 students got a score of 90 , and 2 students got a score of 100 , and the remainder scored 80 so that an average of 86.6 was obtained. The average value of learning outcomes is greater than the KKM that is applied to school standards so based on the exposure above the media considered effective to improve student learning outcomes and character.

One of the goals of SMK revitalization according to the Kementrian Pendidikan dan Kebudayaan (Kemendikbud) is to realize Link and Match with the industrial world. One of the steps to revitalizing SMK is by learning innovation. Learning innovations can be done by developing learning methodologies that strengthen students' abilities. Whereas in addition to academic potential, the industrial world requires a good work culture (soft skills). The process of planting soft skills is good with character education. According to the Strengthening of Character Education is an educational policy whose main purpose is to implement President Joko Widodo's Nawacita, the main values of the characters include Religious, nationalism, intergirtas, mutual cooperation and independence. this is in line with the matcha innovation developed by researchers in the mathcha application. The Math-Cha application uses a contextual approach with character education. One of the implementation of characterbuilding matrix in the Math-Cha application is Pak Jo's honesty canteen. "Pak Jo is a snack businessman who deposits his wares in three school canteens. The price of a packet of peanuts, a packet of crisps, and a pack of sweets in a row is Rp. 5,000.00; Rp. 3,000.00; and Rp 1,000.00. Good relationship and communication made Pak Jo not find any obstacles for sending to the three school canteens. What is the daily income received by $\mathrm{Mr}$. Jo from each canteen as well as the total daily income by presenting a matrix? Try calculating it by matrix multiplication". In that case, students find a new concept that the matrix can be implemented in canteen management. As a reinforcement of the character values contained in the case study of the honesty canteen, Pak Jo is friendly / communicative, honest and hard working. According to Suyadi (2013: 88) the contextual approach is more to the selection of material that is in accordance with daily life experiences that can be used to solve problems. In other words, the contextual approach encourages students to construct their knowledge to be expressed in daily life. Based on interviews with students, at the previous meeting the teacher taught matrix material without Math-Cha media. Student responses to the matrix material is limited to working on problems with the concept of the matrix but do not understand how to implement the concept of the matrix and the usefulness of the matrix in everyday life. After using the Math-Cha media students did not expect that the matrix could be implemented as in the case of Pak Jo. Moreover, through contextual case studies students can draw conclusions about the values contained in a case study. 
DOI: https://doi.org/10.24127/ajpm.v9i1.2655

Students can practice exercises on the Math-Cha application that is repeated in online classes but with a random system so the questions are displayed randomly. The purpose of presenting random questions is to minimize cheating cheating answers with fellow friends to train students' sportsmanship. In practice the questions are given feedback on the wrong answers. If the acquisition value of the practice questions does not meet the completeness standard, students will be directed to remidial by pressing the "Muat Ulang" button. After successfully solving the problem the system will be assessed automatically. Student names and grades will appear on the Scoreboard page. Student responses on the Scoreboard page are very challenged and motivated because of healthy competition between students. Based on observations a student has solved a problem with an initial value of 70. Because seeing other students get a value of 90 then the student tries to work again to get a higher value than his friend. This is consistent with Lickona's opinion to teach students to be responsible for their learning. Through exercises the problem teaches the attitude of sportsmanship in fair competition and the responsibility of solving problems to students. In line with Diani (2015) that the media that were developed effectively could be shown by increasing students competence and activities. Likewise, the research by Suwastika (2018) is the result of hypothesis research with $\mathrm{H} 1$ hypothesis regression with a significance value of 0,000 and the $t-$ test of 4.015 is proven, thus concluded according to STIKOM Bali e-learning students affecting student learning. Mardliyani's research (2017) m-learning significantly supports the independence and learning outcomes of students. So it can be concluded math-cha has good implications for the character building and understanding of students.

\section{CONCLUSION AND RECOMMENDATION}

Based on the research stage that has been done, it can be concluded that the media developed meets the aspects of validity, practicality and effectiveness. Thus, the media mobile learning Math-Cha application developed is suitable for use in mathematics.

Based on the conclusions, the research is to be carried out in the advanced development phase. This math-cha media needs to be developed in other material in mathematics so that it can be utilized at the vocational high school.

\section{REFERENCES}

Aini, A. N., Anggoro, B. S., \& Putra, F. G. (2018). Pengembangan Media Pembelajaran Matematika Pada Materi Transportasi Berbantuan Sparkol. UNION: Jurnal Ilmiah Pendidikan Matematika, 6 (3), 289-296.

Calimag, J. N., Mugel, P. A., Conde, R. S., \& Aquino, L. B. (2014). Ubquitous learning environment using android mobile application. International Journal of Research in Engineering \& Technology, 2 (2), 119-128.

Diani, R. (2015). Pengembangan Perangkat Pembeljaaran Fisika berbasis Pendidikan Karakter dengan Model Problem Based Instruction. Jurnal Ilmiah Pendidikan Fisika Al-Biruni. 4(2), 243-255.

Dewi, N., \& Akhlis, I. (2016). Pengembangan Perangkat 
DOI: https://doi.org/10.24127/ajpm.v9i1.2655

Pembelajaran IPA Berbasis Pendidikan Multikultural Menggunakan Permainan Untuk Mengembangkan Karakter Siswa. Unnes Science Education Journal 5(1), 1098-1108.

Elyas, A. (2018). Penggunaan Model pembelajaran E-Learning Dalam Meningkatkan Kualitas Pembelajaran. Jurnal Warta, 56.

Istiqlal, M., \& Wutsqa, D. U. (2013). Pengembangan Multimedia Pembelajaran Matematika SMA untuk Meningkatkan Motivasi dan Prestasi Belajar Matematika Materi Logika Matematika. Jurnal Pendidikan Matematika PYTHAGORAS, 8 (1), 44-54.

Mahardani, A. S., \& Basalamah, M. R. (2018). Membangun Sumber Daya Manusia Berkarakter Melalui Metode Pendidikan Karakter. Jurnal Ketahanan Pangan, 2(1), 106-116.

Moelbatak, E. (2016). Penerapan Model Multimedia Sebagai Media Pembelajaran Alternatif Untuk Meningkatkan Self Motivated Learning Dan Self Regulated Learning. Jurnal Media Teknika, 11 (2), 83 -90.

Tasri, L. (2011). Pengembangan bahan ajar berbasis web. Jurnal Medtek: $3(2)$.

Sakti, H. P., \& Sujadi, A. A. (2014). Penerapan Pembelajaran Kontekstual untuk meningkatkan minat dan prestasi belajar matematika siswa kelas X SMA negeri Wangon. UNION: Jurnal Ilmiah Pendidikan Matematika, 2(3), 273-280.
Setyadi, D., \& Qohar, A. (2017). Pengembangan Media Pembelajaran Matematika Berbasis Web pada Materi Barisan dan Deret. Jurnal Matematika Kreatif-Inovatif KREANO, 8 (1), 1-7.

Subekti, I., Fitriana, A., Chasanah, C., Riskiana, J., \& Suhartono. (2016). Peran Pendidikan Karakter Dalam Pembentukan SDM Berkualitas Dalam Menghadapi Masyarakat Ekonomi Asean. Prosiding Seminar Nasional Inovasi Pendidikan. Surakarta: Universitas Negeri Sebelas Maret. Suwastika, I. W. K (2018). Pengaruh ELearning Sebagai Salah Satu Media Pembelajaran Berbasis Teknologi Informasi Terhadap Motivasi Belajar Mahasiswa. Jurnal Sistem dan Informatika (JSI), 13 (1), 1-5.

Yadin, M., Rohaeti, E. E., \& Zanthy, L. S. (2019). Meningkatkan Kemampuan pemahaman konsep matematik siswa smp dengan pendekatan kontekstual. Jurnal pembelajaran Matematika Inovatif, 2 (5),337-344. 